\title{
ChemComm
}

Cite this: Chem. Commun., 2013, 49, 2341

Received 4th December 2012, Accepted 5th February 2013

DOI: $10.1039 / \mathrm{c3cc38710k}$

www.rsc.org/chemcomm

\section{A new phenanthroline-oxazine ligand: synthesis, coordination chemistry and atypical DNA binding interaction $\dagger$}

\author{
Malachy McCann, ${ }^{* a}$ John McGinley, ${ }^{a}$ Kaijie Ni, ${ }^{a}$ Mark O'Connor, ${ }^{a}$ Kevin Kavanagh, ${ }^{b}$ \\ Vickie McKee, ${ }^{c}$ John Colleran, ${ }^{d}$ Michael Devereux, ${ }^{d}$ Nicholas Gathergood, ${ }^{e}$ \\ Niall Barron, ${ }^{e}$ Andreea Prisecaru ${ }^{e}$ and Andrew Kellett*e
}

1,10-Phenanthroline-5,6-dione and L-tyrosine methyl ester react to form phenanthroline-oxazine (PDT) from which $\left[\mathrm{Cu}(\mathrm{PDT})_{2}\right]\left(\mathrm{ClO}_{4}\right)_{2}$ and $\left[\mathrm{Ag}(\mathrm{PDT})_{2}\right] \mathrm{ClO}_{4} \cdot 2 \mathrm{MeOH}$ are obtained. Binding to calf-thymus DNA by $\mathrm{Ag}(\mathrm{I})$ and $\mathrm{Cu}(\mathrm{II})$ PDT complexes exceed bis-1,10-phenanthroline analogues and the minor groove binding drugs, pentamidine and netropsin. Furthermore, unlike the artificial metallonuclease, $\left[\mathrm{Cu}(\text { phen })_{2}\right]^{2+}$, the $\left[\mathrm{Cu}(\mathrm{PDT})_{2}\right]^{2+}$ complex does not cleave DNA in the presence of added reductant indicating unique interaction with DNA.

1,10-Phenanthroline (phen), its organic derivatives and the plethora of metal complexes containing these $N, N$ '-chelating heterocycles, find use as optical devices, ${ }^{1,2}$ catalysts $^{3}$ and as integral components of supramolecular structures. ${ }^{4}$ In addition, these compounds have found application in the biological field as antimicrobial and anticancer agents, ${ }^{5}$ DNA intercalators, ${ }^{6}$ and as nucleoside constituents for incorporation into the DNA backbone. ${ }^{7}$

The quest to make new and tailored phenanthrolines is ongoing, and methods include synthesising the bases from elementary building blocks ${ }^{1,8}$ and extending existing, functionalised phenanthrolines. ${ }^{1}$ In the latter context, the quinone, 1,10-phenanthroline5,6-dione (phendio), has been used as the starting material for grafting appendages onto the phenanthroline framework, via simple Schiff base condensation reactions with primary amines. ${ }^{7,9-14}$ However, not all reactions of phendio with primary amines have resulted in the expected Schiff base product. For example, combining phendio with urea ${ }^{15}$ and $N, N^{\prime}$-bis(2-aminophenyl)ethylenediamine ${ }^{16}$

\footnotetext{
${ }^{a}$ Department of Chemistry, National University of Ireland Maynooth, Maynooth, Co. Kildare, Ireland. E-mail: mmcann@nuim.ie; Tel: +35317083767

${ }^{b}$ Department of Biology, National University of Ireland Maynooth, Maynooth, Co. Kildare, Ireland

${ }^{c}$ Chemistry Department, Loughborough University, Loughborough, Leics LE11 3TU, UK

${ }^{d}$ The Inorganic Pharmaceutical and Biomimetic Research Centre, Focas Research Institute, Dublin Institute of Technology, Camden Row, Dublin 8, Ireland

${ }^{e}$ School of Chemical Sciences and National Institute of Cellular Biotechnology, Dublin City University, Glasnevin, Dublin 9, Ireland. E-mail: andrew.kellett@gmail.com; Tel: +35317005461

$\dagger$ Electronic supplementary information (ESI) available: Experimental procedures and biological evaluation studies. CCDC 910336. For ESI and crystallographic data in CIF or other electronic format see DOI: $10.1039 / \mathrm{c} 3 \mathrm{cc} 38710 \mathrm{k}$
}

unexpectedly produced a glycoluril and a gem-cis-bis(aminal), respectively.

Generally, phendio and its $\operatorname{Ag}(\mathrm{I})$ and $\mathrm{Cu}(\mathrm{II})$ complexes are considerably more biologically active than phen and its corresponding metal complexes. ${ }^{5 a, b}$ With this in mind, we sought to improve biological activity, selectivity and compatibility by attempting to prepare a double Schiff base, phen-type ligand by reacting phendio with two equivalents of (S)-methyl 2-amino-3-(4-hydroxyphenyl)propanoate (L-tyrosine methyl ester).

Phendio was initially treated with L-tyrosine methyl ester (1:2 mol ratio) in anticipation of forming a double Schiff base condensation product (Scheme 1). Unexpectedly, this combination produced 1,10-phenanthroline-5,6-diol and a relatively low yield of the new orange-yellow tetracyclic oxazine, PDT. The structure of PDT.MeOH (Fig. 1) showed that chirality within the compound is retained, with $\mathrm{C} 13$ being the stereogenic centre (originally it was $\mathrm{C} 20$ ). The molecule crystallises in the centrosymmetric space group, $P 2_{1} / c$, and so is a racemic mixture. Interestingly, the phenol ring is almost orthogonal to the oxazine ring (bond angle $89.12(2)^{\circ}$ ) forming a 'chair' profile. The pdtme molecules are linked into zig-zag chains via hydrogen bonding through the methanol solvate; the phenol group makes a H-bond to the oxygen of the methanol (2.6288(18) $\AA$ ), and the methanol $\mathrm{OH}$ makes an unsymmetric, bifurcated $\mathrm{H}$-bond to the phenanthroline nitrogen atoms of a second molecule (3.028(2) and 2.907(2) A to N1 and N2, respectively, under symmetry operation $-x+2, y-1 / 2,-z+3 / 2)$.

What is the mechanism of the cyclization reaction that leads to the formation of the oxazine ring in pdtme? In their paper on the oxidation of $\alpha$-amino acids by quinones, Lourak and co-workers ${ }^{17}$ obtained cyclic derivatives containing oxazine rings. These researchers

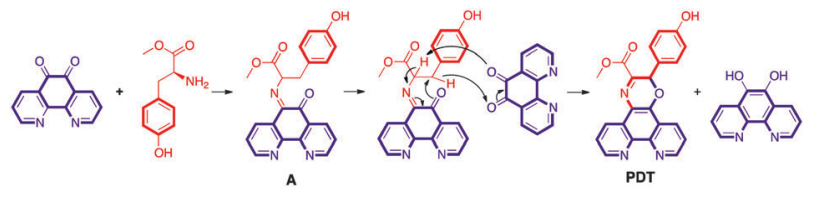

Scheme 1 Proposed reaction mechanism of phendio with L-tyrosine methyl ester leading to the formation of PDT. 

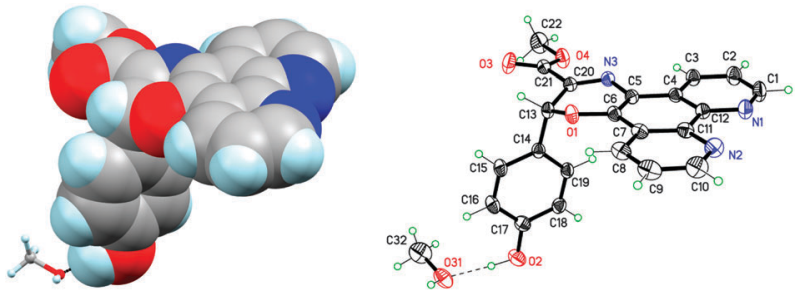

Fig. 1 Space-fill view of pdtme in PDT.MeOH (MeOH shown in stick view) (left) and a view of PDT.MeOH with $50 \%$ ADPs (right).

proposed a mechanism for their reaction in which a second quinine molecule acted as a dehydrogenating agent to give the cyclic product. In the present work, the isolation of 1,10-phenanthroline-5,6-diol as a by-product of the reaction suggested that reduction of some phendio was occurring as part of the reaction mechanism. A likely first step is the formation of a Schiff base (molecule $\mathbf{A}$ in Scheme 1). A plausible, concerted mechanism for formation of the oxazine ring is offered in Scheme 1 and involves the participation of a second phendio molecule as a dehydrogenating agent. Due to steric restraints, resulting from both $\mathbf{A}$ and phendio, this reaction is expected to be slow, as was observed.

Interestingly, in the preparation of the phendio-amino acid ternary complexes, [Cu(phendio)(L-Phe) $\left.\left(\mathrm{H}_{2} \mathrm{O}\right)\right] \mathrm{ClO}_{4} \cdot \mathrm{H}_{2} \mathrm{O}$ and [Ni(phendio)$\left.(\mathrm{Gly})\left(\mathrm{H}_{2} \mathrm{O}\right)\right] \mathrm{ClO}_{4} \cdot \mathrm{H}_{2} \mathrm{O}(\mathrm{L}-\mathrm{PheH}=\mathrm{L}-$ phenylalanine, $\mathrm{GlyH}=$ glycine $)$, no interaction between the phendio carbonyl functions and the amine group of the amino acid was reported.$^{18}$ Reaction of PDT with $\mathrm{AgClO}_{4}$ in a ca. 2:1 molar ratio gave the green solid, $\left[\mathrm{Ag}(\mathbf{P D T})_{2}\right] \mathrm{ClO}_{4} \cdot 2 \mathrm{MeOH}$ (AgPDT), in good yield. The complex cation, $\left[\mathrm{Ag}(\mathbf{P D T})_{2}\right]^{+}$, is thought to be essentially isostructural with the cation in the structurally characterised complex, $\left.[\mathrm{Ag} \text { (phendio })_{2}\right] \mathrm{ClO}_{4},{ }^{19}$ where the metal has approximately tetrahedral geometry. In comparison to the ${ }^{1} \mathrm{H}$ NMR spectrum of metal-free PDT, the spectrum of AgPDT showed shifts in the signals associated with the phen part of the pdtme molecule rather than the ester part of the molecule, indicating that the $\mathrm{Ag}^{+}$ ion is chelated by the two nitrogen atoms. In a similar reaction using $\mathrm{Cu}\left(\mathrm{ClO}_{4}\right)_{2} \cdot 6 \mathrm{H}_{2} \mathrm{O}$, the green solid, $\left[\mathrm{Cu}(\mathbf{P D T})_{2}\right]\left(\mathrm{ClO}_{4}\right)_{2}$ (CuPDT), was obtained in moderate yield. Again, it is believed that $\left[\mathrm{Cu}(\mathbf{P D T})_{2}\right]^{2+}$ is structurally similar to the known tetrahedral cation in $\left[\mathrm{Cu}(\text { phen })_{2}\right]\left(\mathrm{ClO}_{4}\right)_{2}(\text { CuPhen })^{20}$

In an effort to establish how the metal-free PDT ligand and its $\mathrm{Cu}(\mathrm{II})$ and $\mathrm{Ag}(\mathrm{I})$ complexes interact with DNA four distinct assays were conducted. To establish an apparent DNA binding constant $\left(K_{\text {app }}\right)$ a sample of high-purity calf thymus (CT) DNA is firstly treated with an excess of $\mathrm{EtBr}$ and then this highly fluorescent, $\mathrm{Et}^{+}$-saturated DNA sample is exposed to a range of concentrations of the competitor test compound. A reduction in fluorescence indicates ejection of the bound $\mathrm{Et}^{+}$from the DNA backbone and replacement by the test species. Samples are compared based on their $K_{\text {app }}$ values, which are calculated from the concentration of sample required to accomplish a 50\% reduction of the initial fluorescence (Fig. 2 and Table 1). Metal-free PDT, phen and the simple metal salts all showed considerably less DNA binding affinities than AgPDT and CuPDT, which have almost identical $K_{\text {app }}$ values. The Ag(I) and $\mathrm{Cu}$ (II) PDT complexes also showed a higher binding capacity than the known groove-binding drugs, pentamidine and netropsin.

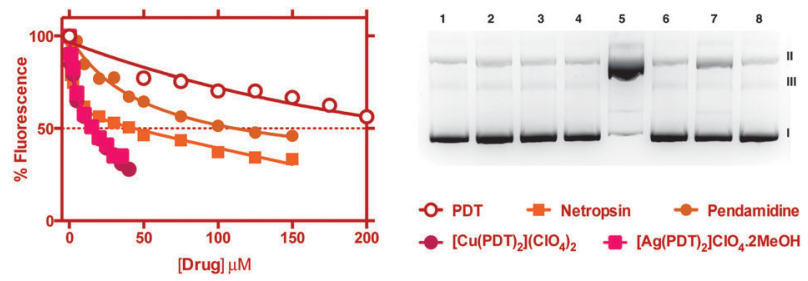

Fig. 2 Competitive EtBr displacement with CT-DNA (left) and DNA cleavage reactions of pBR322 plasmid DNA (400 ng) with $1 \mathrm{mM} \mathrm{Na-L-ascorbate} \mathrm{analysed} \mathrm{on} \mathrm{agarose} \mathrm{gel}$ electrophoresis (right). Lane 1: DNA control; lane 2: [Cu(OAc) 2 ; lane 3: $\mathrm{AgNO}_{3}$; lane 4: PDT; lane 5: CuPhen; lane 6: AgPhen; lane 7: CuPDT; lane 8: AgPDT.

The binding of metal-free PDT to DNA is significantly stronger than that of metal-free phen, suggesting that the additional functionalities on the backbone provide secondary binding interactions with the nucleic acid. The contribution of these extra interactions is also apparent when the binding constants of PDT and phen metal complexes are compared ( $K_{\text {app }}$ for AgPDT is $\sim 3$ times larger than AgPhen and CuPDT is $\sim 11$ times that of CuPhen).

Competitive displacement of DNA-bound Hoechst 33258 (minor groove binder) and ethidium cations ( $\mathrm{Et}^{+}$, intercalator) was assessed using fluorescence quenching, which utilises an unsaturated dyeDNA combination in which a limited number of binding spaces on the DNA polymer are occupied at any one time by the interacting dye, which strongly fluoresces once bound with a relatively high number of unoccupied sites remaining for test compound interaction. The introduction of a new compound to the DNA may then displace Hoechst or $\mathrm{Et}^{+}$either directly or indirectly (i.e. through a conformational change which results in dye ejection) and can give valuable information regarding a binding interaction mode ${ }^{21}$ although, caution must be exercised here considering the binding constant and binding stoichiometry of ethidium bromide and Hoechst to CT-DNA. The minor groove binders, pentamidine and netropsin, displayed high quenching affinity $(Q)$ for Hoechst 33258 bound DNA and were, as expected, an order of magnitude less effective in their quenching of ethidium (Table 1). Both AgPhen and CuPhen displayed higher $Q$ values toward $\mathrm{Et}^{+}$than compared with Hoechst. Interestingly, both AgPDT and CuPDT displayed higher $Q$ values, along with different profiles, $\uparrow$ and were almost identical in their ejection of bound Hoechst and $\mathrm{Et}^{+}$. From these quenching data it is evident that the

Table 1 Apparent DNA binding constants $\left(K_{\text {app }}\right)$ of the test compounds and fluorescence quenching $(Q)$ values

\begin{tabular}{lclll}
\hline Compound & $C_{50}{ }^{a}(\mu \mathrm{M})$ & $K_{\text {app }}{ }^{b}$ & $\begin{array}{l}Q^{c} \text { Hoechst } \\
33258(\mu \mathrm{M})\end{array}$ & $\begin{array}{l}Q^{c} \text { Ethidium } \\
\text { bromide }(\mu \mathrm{M})\end{array}$ \\
\hline Pentamidine & 109.41 & $1.09 \times 10^{6}$ & 35.86 & $>150$ \\
Netropsin & 39.99 & $4.77 \times 10^{6}$ & 3.50 & 35.98 \\
AgPDT & 15.75 & $7.60 \times 10^{6}$ & 24.65 & 18.18 \\
CuPDT & 15.70 & $7.62 \times 10^{6}$ & 18.00 & 18.59 \\
AgPhen & 45.01 & $2.65 \times 10^{6}$ & 45.54 & 27.90 \\
CuPhen & 179.21 & $6.67 \times 10^{5}$ & 34.96 & 20.38 \\
1,10-Phen & $>300$ & N/A & - & - \\
PDT & 247.21 & $4.80 \times 10^{5}$ & - & - \\
AgClO & $>300$ & N/A & - & - \\
{$\left[\mathrm{Cu}(\mathrm{OAc})_{2}\right]$} & $>300$ & N/A & - & -
\end{tabular}

${ }^{a} \mathrm{C}_{50}=$ concentration required to reduce fluorescence by $50 \% .{ }^{b} K_{\text {app }}=$ $K_{\mathrm{e}} \times 12.6 / \mathrm{C}_{50}$ where $K_{\mathrm{e}}=9.5 \times 10^{6} \mathrm{M}(\mathrm{bp})^{-1} ; \mathrm{N} / \mathrm{A}=$ not available. ${ }^{c} Q=$ reduction of $50 \%$ initial fluorescence from DNA-bound dye. 


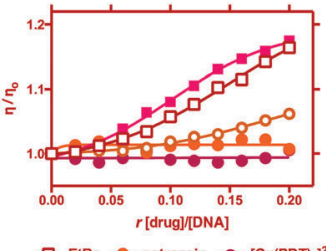

$\rightarrow$ EtBr - netropsin $-\left[\mathrm{Cu}(\mathrm{PDT})_{2}\right]^{2+}$

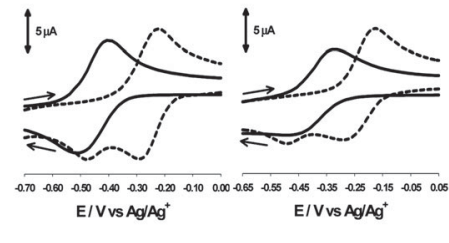

Fig. 3 Relative viscosity changes in salmon testes dsDNA (left) and cyclic voltammograms describing the redox behavior of $1 \mathrm{mM}$ CuPhen (centre) and CuPDT (right), at a scan rate of $100 \mathrm{mV} \mathrm{s}^{-1}$, in the absence (solid black trace) and presence (dashed black trace) of $2 \mathrm{mM}$ ascorbate. $t$

PDT complexes have significantly higher binding affinities $\left(K_{\text {app }}\right)$ and an alternate binding mode compared with their bis-phen analogues.

Viscosity experiments were conducted using salmon testes dsDNA (1 mM in DNAp) (Fig. 3).† Intercalating agents (e.g. ethidium) are known to increase viscosity which results from a conformational change induced after accommodation between DNA bases, while surface binding species (e.g. netropsin) can typically have only a moderate or diminished effect on viscosity. This expected pattern emerged during our analysis of both these standard agents (Fig. 3). It was also evident that CuPhen, containing the $\left[\mathrm{Cu}(\text { phen })_{2}\right]^{2+}$ cation, produced an intercalative profile while, significantly, CuPDT did not appear to intercalate DNA but had a profile similar to the surface binding drugs, netropsin and pentamide. Furthermore, the viscosity profile for CuPDT was distinctive from that of the partial intercalating mono-phen complex, $[\mathrm{Cu}(\text { phen })]^{2+}$.

Relaxation of supercoiled pBR322 (Form I) into open circular (Form II) and linear (Form III) conformations was used to quantify the relative DNA cleavage efficiency (nuclease activity) of the test complexes. DNA cleavage by $\left[\mathrm{Cu}(\text { phen })_{2}\right]^{2+}$ is known to be dependent on the presence of added oxidant and/or reductant, and the assay was conducted in an aerobic environment $\left(\mathrm{O}_{2}\right.$ oxidant) along with the addition of a $1 \mathrm{mM}$ solution of the reductant, sodium L-ascorbate. Samples $(5 \mu \mathrm{M})$ were incubated for $30 \mathrm{~min}$ at $37{ }^{\circ} \mathrm{C}$ before being quenched and analysed using gel electrophoreses. The only complex found to be active (Fig. 2) was the known chemical nuclease, $\left[\mathrm{Cu}(\text { phen })_{2}\right]^{2+} \cdot 22$ This dication renders almost complete degradation of Form I to linear Form III by interacting at the surface of the minor groove of DNA and in the presence of a reductant, which can gain access to the $\mathrm{Cu}$ (II) centre in the complex, DNA oxidation occurs predominantly in this region. It was somewhat surprising that CuPDT was almost inactive compared with $\left[\mathrm{Cu}(\text { phen })_{2}\right]^{2+}$. Furthermore, any role that the phenol moiety in PDT may play in scavenging free radicals to prevent DNA damage looks quite unlikely as CuPhen, incubated with up to $100 \mu \mathrm{M}$ of phenol, produced only a marginal inhibition of pBR322 cleavage (Fig. S3). $†$

The redox behaviour of CuPhen and CuPDT was investigated, using cyclic voltammetry, to shed light on the observed differences in their efficacy as DNA nuclease agents (Fig. 3 and Fig. S4-S9). $†$ The $\mathrm{Cu}(\mathrm{II}) / \mathrm{Cu}(\mathrm{I})$ redox couple was centred around -0.46 and $-0.39 \mathrm{~V}$ for CuPhen and CuPDT, respectively. Addition of $2 \mathrm{mM}$ ascorbate results in a significant anodic shift in the $\mathrm{Cu}(\mathrm{II}) / \mathrm{Cu}(\mathrm{I})$ redox couple of both complexes, indicative of a more facile electron transfer regime. The original $\mathrm{Cu}(\mathrm{II})$ reduction peak for $\mathbf{C u P h e n}$ is observed at $-0.47 \mathrm{~V}$ but, interestingly, is not evident at scan rates $\leq 40 \mathrm{mV} \mathrm{s}^{-1}$, which suggests a transient species. While CuPhen tends toward reversibility in the presence of ascorbate $\left(\Delta E_{\mathrm{P}}=65 \mathrm{mV}\right)$, CuPDT remains quasi-reversible $\left(\Delta E_{\mathrm{P}}=119 \mathrm{mV}\right.$, Table S1, ESI $\dagger$ ). Thus, the reversibility of the $\mathrm{Cu}^{2+} / \mathrm{Cu}^{+}$couple may justify the greater DNA cleavage ability of CuPhen.

For concluding remarks please see ESI. $†$

\section{Notes and references}

1 A. Bencini and V. Lippolis, Coord. Chem. Rev., 2010, 254, 2096-2180. 2 (a) V. W. W. Yam, C. C. Ko and N. Zhu, J. Am. Chem. Soc., 2004, 126, 12734-12735; (b) R. A. Kopelman, S. M. Snyder and N. L. Frank, J. Am. Chem. Soc., 2003, 125, 13684-13685.

3 G. Roelfs and B. L. Feringa, Angew. Chem., Int. Ed., 2005, 44, 3230-3232.

4 (a) G. Accorsi, A. Listorti, K. Yoosaf and N. Armaroli, Chem. Soc. Rev., 2009, 38, 1690-1700; (b) A. Lavie-Cambot, M. Cantuel, Y. Leydet, G. Jonusauskas, D. Bassani and N. McClenaghan, Coord. Chem. Rev., 2008, 252, 2572-2584; (c) D. Scaltrito, D. Thompson, J. O'Callaghan and G. Meyer, Coord. Chem. Rev., 2000, 208, 243-266; (d) P. H. Kwan, M. J. Maclachlan and T. M. Swager, J. Am. Chem. Soc., 2004, 126, 8638-8639; (e) G. R. Pabst, O. C. Pfüller and J. Sauer, Tetrahedron Lett., 1998, 39, 8825-8828.

5 (a) M. McCann, A. L. S. Santos, B. A. da Silva, M. T. V. Romanos, A. S. Pyrrho, M. Devereux, K. Kavanagh, I. Fichtner and A. Kellett, Toxicol. Res., 2012, 1, 47-54, and references therein; (b) M. McCann, A. Kellett, K. Kavanagh, M. Devereux and A. L. S. Santos, Curr. Med. Chem. 2012, 19, 2703-2714, and references therein; (c) A. Shulman and F. P. Dwyer, in Chelating Agents and Metal Chelates, ed. F. P. Dwyer and D. P. Mellor, Academic Press, New York and London, 1964, ch. 9.

6 (a) K. E. Erkkila, D. T. Odom and J. K. Barton, Chem. Rev., 1999, 99, 2777-2796; (b) A. M. Thomas, M. Nethaji and A. R. Chakravarty, J. Inorg. Biochem., 2004, 98, 1087-1094; (c) C. Chen, L. Milne, R. Landgraf, D. Perrin and D. Sigman, ChemBioChem, 2001, 2, 735-740; (d) H. Niyazi, J. P. Hall, K. O'Sullivan, G. Winter, T. Sorenson, J. M. Kelly and C. J. Cardin, Nat. Chem., 2012, 4, 621-628; (e) H. Song, J. T. Kaiser and J. K. Barton, Nat. Chem., 2012, 4, 615-620; $(f)$ T. K. Goswami, S. Gadadhar, A. A. Karande and A. R. Chakravarty, Polyhedron, 2013, in press, http://dx.doi.org/10.1016/j.poly.2012.06.018.

7 (a) K. Gislason and S. T. Sigurdsson, Eur. J. Org. Chem., 2010, 4713-4718; (b) J. Muller, Eur. J. Inorg. Chem., 2008, 3749-3763.

8 Y. Cheng, X. Han, H. Ouyanga and Y. Rao, Chem. Commun., 2012, 48, 2906-2908.

9 J. E. Dickeson, L. A. Summers and A. Lindsay, Aust. J. Chem., 1970, 23, 1023-1027.

10 B. Krishnakumar and M. Swaminathan, J. Organomet. Chem., 2010, 695, 2572-2577.

11 V. W.-W. Yam, K. K.-W. Lo, K.-K. Cheung and R. Y.-C. Kong, J. Chem. Soc., Chem. Commun., 1995, 1191-1193.

12 F. da Silva Miranda, A. M. Signori, J. Vicente, B. de Souza, J. P. Priebe, B. Szpoganicz, N. SanchesGonçalves and A. Neves, Tetrahedron, 2008, 64, 5410-5415.

13 J. Bolger, A. Gourdon, E. lshow and J.-P. Launay, J. Chem. Soc., Chem. Commun., 1995, 1799-1800.

14 G. R. Pabst, O. C. Pfüller and J. Sauer, Tetrahedron Lett., 1998, 39, $8825-8828$.

15 J. A. A. W. Elmens, R. de Gelder, A. Rowan and R. J. M. Nolte, J. Chem. Soc., Chem. Commun., 1998, 1553-1554.

16 B. Coyle, M. McCann, V. McKee and M. Devereux, ARKIVOC, 2003, 7(VII), 59-66.

17 M. Lourak, R. Vanderesse, A. Vicherat, J. Jamal-Eddinea and M. Marraud, Tetrahedron Lett., 2000, 41, 8773-8776.

18 G.-J. Xu, Y.-Y. Kou, L. Feng, S.-P. Yan, D.-Z. Liao, Z.-H. Jiang and P. Cheng, Appl. Organomet. Chem., 2006, 20, 351-356.

19 M. McCann, B. Coyle, S. McKay, P. McCormack, K. Kavanagh, M. Devereux, V. McKee, P. Kinsella, R. O'Connor and M. Clynes, Biometals, 2004, 17, 635-654.

20 G. Murphy, C. Murphy, B. Murphy and B. Hathaway, J. Chem. Soc., Dalton Trans., 1997, 2653-2660.

21 A. Kellett, O. Howe, M. O'Connor, M. McCann, B. S. Creaven, S. McClean, A. Foltyn-Arfa, A. Casey and M. Devereux, Free Radicals Biol. Med., 2012, 53, 564-576.

22 D. S. Sigman, D. R. Graham, V. D'Aurora and A. M. Stern, J. Biol. Chem., 1979, 254, 12269-12272. 